\title{
Ethnologies
}

\section{Protest Song and Verse in Cape Breton Island}

\section{Richard MacKinnon}

Volume 30, numéro 2, 2008

Hommage à Peter Narváez

In Honour of Peter Narváez

URI : https://id.erudit.org/iderudit/019945ar

DOI : https://doi.org/10.7202/019945ar

Aller au sommaire du numéro

\section{Éditeur(s)}

Association Canadienne d'Ethnologie et de Folklore

ISSN

1481-5974 (imprimé)

1708-0401 (numérique)

Découvrir la revue

Citer cet article

MacKinnon, R. (2008). Protest Song and Verse in Cape Breton Island. Ethnologies, 30(2), 33-71. https://doi.org/10.7202/019945ar

\section{Résumé de l'article}

Sur l'île du Cap-Breton, où les mines de charbon et les aciéries constituaient autrefois une composante essentielle de la culture et de l'économie de la région, la chanson et le poème de contestation sont très courants. Cet article explore certains chansons et poèmes de contestation de l'île du Cap-Breton qui n’avaient jusque-là pas été étudiés. Le corpus de chansons provient pour la plupart du Maritime Labour Herald, un quotidien des années 1920 qui incluait des oeuvres composées sur place et ailleurs dans le monde. Dans le passé, certains ethnologues ont écarté les chansons de contestation car leurs paradigmes ne leur permettaient pas d'appréhender ces dernières comme des modes d'expression culturels authentiques. Leur approche soulève des questions complexes sur comment et par qui se construit l'authenticité. Mon propos ici est de démontrer qu'une tradition de chansons de contestation très évoluée a bien et bel existé et a joué un rôle important dans les luttes travaillistes des années 1920. En effet, ces documents vernaculaires affermirent la solidarité au cours des moments de bouleversement et de changement à l'île du Cap-Breton.
Ce document est protégé par la loi sur le droit d'auteur. L'utilisation des services d'Érudit (y compris la reproduction) est assujettie à sa politique d'utilisation que vous pouvez consulter en ligne.

https://apropos.erudit.org/fr/usagers/politique-dutilisation/ 


\title{
Protest Song and Verse in Cape Breton Island
}

\author{
Richard MacKinnon \\ Cape Breton University
}

In regional enclaves throughout North America where labour and capital have fought battles over the years, there are many songs and verses about labour and protest. Folklorist Peter Narváez conducted pioneer research on the protest song tradition and the use of strike songs in the company town of Buchans, Newfoundland (2005). Others have examined the songs and verses of miners and their families, and the diversity of folklore found in mining communities (Green 1972; Korson 1960, 1964, 1965; Lloyd 1952; Greenway 1970; O’Donnell 1992). On Cape Breton Island, where coal mining and steel making were once an essential part of the region's culture and economy, protest song and verse are found in abundance (Frank 1985, 1986). This article explores some previously unexamined protest songs and verses of Cape Breton Island.

I will show how these vernacular materials were used for solidarity during times of upheaval and change in the mid 1920s. I will examine a body of songs culled largely from the Maritime Labour Herald, a newspaper of the 1920s that included both locally and internationally composed works. Some earlier folklorists ignored protest songs because their paradigms did not permit them to view these forms as authentic cultural expressions. Their approach raises complex issues of how authenticity is constructed and by whom. My intent is to show that a well-developed protest song tradition was alive and well and played an important role in the labour struggles of the 1920s. 
Coal was last mined in Cape Breton in 2001, but people continue to find relevance in this repertoire via one of Canada's only coal mining choirs, the Men of the Deeps, which keeps the songs of the earlier period alive. Jack O'Donnell, a music professor at St. Francis Xavier University in Antigonish, Nova Scotia, founded the choir in 1966 in anticipation of Canada's centennial celebration. With an interest in coal mining songs, O'Donnell began a search for material and sponsored a songmaking contest. The result was an assemblage of numerous old and new songs about industrialization and the mining industry. Since then, the choir and its director have performed throughout the world, cut professional recordings, and published books on coal mining songs (O'Donnell 1975, 1992a, 1992b). To enable these endeavours, O'Donnell obtained the sanction of mine management, which included securing wages for missed time when choir members were practicing or traveling around the world.

O'Donnell introduced songs to the choir's repertoire from the Korson and Greenway mining song collections and ultimately brought the repertoire out of kitchens and community halls into the more formal setting of the theatre and concert hall. While the notion of a miners' choir was traditional in some areas of the British Isles, there does not seem to be a precedent in Cape Breton; there, it was more common for a person with an untrained voice to sing a cappella. ${ }^{1}$ It was also customary for individual miners to sing as they traveled in the man-rake to their work site. ${ }^{2}$ This move from individual to large group singing in three or four part harmonies is a transformation that has allowed this song tradition to continue. O'Donnell's choir has spawned keen interest in songs of this kind; now, it is common to hear material popularized by the Men of the Deeps sung by individuals with guitar accompaniment at house parties and other informal gatherings.

The songs have influenced the expressive culture of the company towns of Cape Breton Island. As defined by Narváez, the company town is a single enterprise community "where major areas of social and

1. For a discussion of the choral singing tradition of Welsh miners see Williams 1998. At the end of the nineteenth century, choral singing was an important aspect of many Welsh mining villages and song competitions were part of the tradition (see Rhoss Male Voice Choir).

2. A man-rake is the conveyance system that takes men into and out of the coal mines. These are connected box cars that in the past were made of wood; more recent ones were made of steel. 
cultural life such as food procurement, housing, friendship groups, entertainments and public activities are either company dominated or at least highly influenced by company policies and concerns" (2005: 300 ). He points out that these communities are of interest to folklorists as they possess the characteristics of traditional folk societies as well as those of complex urban societies.

Folklorists and other scholars refer to protest songs by various monikers. They have debated the nuances in meanings of terms such as "labour lore," "industrial lore," "industrial folksong," "protest song," "propaganda song," "occupational folklore," "occupational folklife" and "organizational folklore" (American Folklore Society 1984; Denisoff 1966; Fowke 1969; Frank, 1985: 213; Jones 1985; McCarl 1978: 176). Edith Fowke claims that, "although Canada is very rich in occupational songs, we have comparatively few industrial or labour songs" (1969: 34). While collectors of folksong throughout Canada have not assiduously searched for material about industry or labour, Canada does in fact possess an abundance of such songs, contrary to Fowke's statement. It is her paradigm as a song collector primarily interested in older folksongs and ballads that prevents her from viewing these kinds of songs as authentic or legitimate traditions that make up a song repertoire in an industrial community (Greenhill 2003). John Greenway's simple definition of protest songs is more useful: "[t]hese are the struggle songs of the people. They are the outbursts of bitterness, of hatred for the oppressor, of determination to endure hardships together and to fight for a better life" (1970: 10). He sees them as promoting unity and communality, togetherness and support for a union.

Before assessing the song and verse, I will take a cursory look at the historical context of coal and steel development on Cape Breton Island. Coal was being mined in the region as early as the eighteenth century to serve as fuel for the fireplaces at the fishing entrepôt of Louisbourg. It was not until the early nineteenth century, however, that the Britishowned General Mining Association began to build pitheads, company stores and company housing in the Sydney coal fields. During the latter half of the nineteenth century, a number of private enterprises operated mines in Cape Breton, but by 1893, some of the smaller companies amalgamated to form a syndicate, Dominion Coal Company. This group built piers and discharging plants in Boston and loading facilities in Sydney and Louisbourg. By 1898, this company was transformed into Dominion Iron and Steel Corporation with the intention of constructing 
a steel plant in Sydney. Labour historian Don MacGillivray points out that by this time Cape Breton Island "held approximately one-fifth of the total provincial population; two-thirds of the provincial revenue came from the area, as did seventy-five percent of Dominion Steel's coal - in national terms Cape Breton's contribution accounting for forty-five percent of the country's entire coal production" (1973: 50).

There was much industrial activity on Cape Breton Island at the turn of the twentieth century. It was this development and the conflicts between labour and capital which followed that sparked the creativity of song and verse makers. The fact that the management team spent no more than a few years in the coalfields and never put down roots on the Island accentuated some of the conflicts. Managers were referred to in Cape Breton as "floaters," having "no stake in the community and no love for the people" (Frank 1971: 43). On the occasion of Dominion Coal Company's incorporation, its president H.M. Whitney stated that his work and life would be one with the people of Cape Breton. Less than five years later, however, he left the Island and sold his interests to a Montreal consortium - the British Empire Steel and Coal Corporation (BESCO) - led by Roy Wolvin, a Great Lakes shipping entrepreneur (MacGillivray 1979). Under Wolvin's leadership, BESCO's treatment of the Cape Breton worker was ruthless and hard-hearted. Social and living conditions were deplorable, wages in the steel mill and coal mines were low under his management, and labour/management conflict was common (MacGillivray 1973, 1978, 1979).

The Cape Breton songs I explore here come out of this working class tradition: many were composed and published in the 1920s, when miners battled foreign-owned companies and struggled to form unions. The songs closely follow Greenway's definition of protest songs. They express the attitudes of coal miners and their families; many discuss oppression, exploitation, hardship, and successful struggle through solidarity. They are often accompanied by a large dose of humour, satire, sarcasm, and wit, attesting to the vibrant oral tradition of the day. I am not, however, the first to appreciate that these songs are a valuable source for the interpretation and study of Cape Breton's cultural traditions (Frank, 1985, 1986; O’Donnell, 1992a, 1992b). Looking at a previously unexamined corpus of song and verse that originally appeared in The Maritime Labour Herald, a Glace Bay newspaper, throughout the 1920s allows me to understand who the composers are, where they are from, the date of composition and the tune or air if mentioned. 
One hundred and twenty-four songs and verse appeared in the paper between 1921 and 1926 (see Appendix 1). Almost half of the songs and verses (55) are of Cape Breton Island composition. Other places of origin include industrial centres such as Glasgow, Germany, Florence, the Republic of Ireland, and England. American regions such as West Virginia, New England, and Memphis are represented, as are Canadian cities such as Ottawa and Montreal, and smaller Nova Scotia mine districts such as Springhill and Westville. This geographical representation speaks volumes about this Glace Bay newspaper's wide appeal in labour circles of the 1920s. "Canada Free" is one of only five of the songs which is presented with its air or music; it is said to be sung to "The Maple Leaf" and the musical notation is provided with the lyrics (Maritime Labour Herald 10 December 1922: 5). Other tunes for songs include "Yankee Doodle Dandy," "Oh Canada," "My Mayland, My Mayland" and "Maryland" (Maritime Labour Herald 3 December 1921: 5; 7 October 1922: 7; 28 April 1932: 8; 15 May 1926: 4).

These songs I am exploring can be called protest songs. Though Fowke limits her definition of industrial songs to "those describing any form of work" (1969: 34), Archie Green extends the idea when he notes that, "[a]n industrial folksong describes work itself and portrays the life, diversions and struggles of men on the job" (1972: 8). But as I will show, song and verse of industrial protest can also refer to activities beyond the domain of work and can include references to important individuals and events in communities at times of struggle, strife, or strike. In the body of material examined here, satire and humour also play a significant role.

As is shown by, for example, George Korson's deletion of a large quantity of songs from his study due to personal political convictions, individuals who research songs of industrial protest are often selective about the kinds of songs designated under that rubric. ${ }^{3}$ Korson describes his criteria for selection in a letter to Archie Green: "When I found that [a ballad] had been written by an outsider I didn't use it.... I had to be especially careful because in the 1920s and 30s the communists

3. George Korson, one of the most prolific American collectors of mining songs and lore, did not formally conduct fieldwork in Cape Breton. However, at a union conference in the United States he met Bob Stewart, a coal miner from Glace Bay, and collected some of his songs. Korson recorded songs such as "Jolly Wee Miner Man," "The Bumps," "The Yahie Miners" and "Arise Ye Nova Scotia Slaves" (Korson 1965: 103-04, 236, 334, 424). 
were making a determined effort to capture the United Mine Workers of America, and some of their songs were composed by their organizers. When I was sure of this source - and I had ways of finding out - I just didn't use the song in my collection" (1972: 18).

This practice of designating a protest song based on the affiliation or political persuasion of the composer is questionable. While many of the songs I analyze were indeed composed by members of the Communist Party of Canada, I contend that the more important concerns ought to be whether or not the song entered oral tradition, for how long, and whether or not the song held meaning for people.

Addressing these concerns can be complex, for in many cases our only record of the so-called songs are newspaper accounts or songbooks that offer the lyrics without the accompanying music. Often, the contemporary reader is not provided with a composer's name and pseudonyms are commonly employed to protect her or his identity. Furthermore, as Greenway and Narváez have shown, protest song and verses do not often acquire the trait of persistence and sometimes do not last long beyond the event or incident for which they are created (Greenway 1953: 3; Narváez 2005).

One song and verse maker from Cape Breton Island whom Korson would not have acknowledged because of his left-wing, Communist political perspective is Donald "Dawn" Fraser. Born on 1 July 1888 in Oxford, Nova Scotia, he moved with his family to Glace Bay in 1901 when the Cape Breton industrial communities were booming with coal and steel development. After travelling through the eastern United States and serving a short stint in the army, he returned to Cape Breton Island in 1919 to begin writing song and verse about the discontent amongst the labouring classes (Frank and MacGillivray 1976: 10). One scholar argues that the intense class conflict that emerged in Cape Breton in the 1920s "grew out of the intersection of two historical cycles: the coal miners' embrace of the heightened aspirations and class consciousness that swept the European and North American working class following the Bolshevik revolution and the end of World War I; and the arrival of BESCO, a new and particularly aggressive industrial landlord eager to exploit coal holdings that formed the most profitable part of its operations but which were becoming increasingly vulnerable to extra-provincial competitive pressures" (Manley 1992: 66). Fraser entered the fray of labour's wars by composing poems and songs that 
represent the feelings and attitudes of working class people in this era; he became a vocal critic of the BESCO corporation.

Described as "Cape Breton's nearest equivalent to Joe Hill," ${ }^{4}$ Fraser was not a coal miner but a newspaper reporter who frequently contributed to The Maritime Labour Herald (Frank and MacGillivray 1976: 10). This newspaper became significant in the class struggles of the early 1920s and was one of the "key institutions" to support the Communist Party of Canada, along with the Workers Educational Clubs and the Communist Party headquarters in Glace Bay (Manley 1992: 85). The first edition of the paper was published in Glace Bay in late October, 1921 with James B. McLachlan as the "dominant spirit," and William Ulric Cotton as the first editor (MacEwan 1976: 74). Silby Barrett was President, A.S. MacIntyre, Vice President and A.S. McKillop, Secretary-Treasurer (The Maritime Labour Herald 1 April 1922: 3)..$^{5}$ It was published every Saturday and was "devoted to the interests of Labour" (The Maritime Labour Herald 1 April 1922: 3). The majority of the shares in the paper were held by unions of the day and, "until it folded in $1926 \ldots$ it was to all intents a party paper, described on one occasion by Tim Buck as a Maritimes version of Lenin's collective organizer" (Manley 1992: 86). The reference to the newspaper as Lenin's collective organizer derives from a famous quotation of Lenin's in 1903:

The role of a newspaper, however, is not limited solely to the dissemination of ideas, to political education, and to the enlistment of political allies. A newspaper is not only a collective propagandist and a collective agitator, it is also a collective organizer (Socialist Worker On-line).

4. Industrial Workers of the World (IWW) organizer Joe Hill was well known for his songs about labour and class consciousness before his execution in 1915.

5. According to David Frank, "Silby Barrett was a young Newfoundlander who had gone from the fishing boats to the coal mines as a young man. After working in Ohio he had been converted to the union cause, and by the time he settled in Glace Bay in 1908 he was a strong UMW supporter. Unschooled but possessed of a flamboyant personality and a salty wit, Barrett came under McLachlan's influence...." (1999: 120-121). William Ulric Cotton was a "young Eastern townships lawyer" who had previous experience as editor of Cotton's Weekly, "Canada's most popular socialist newspaper” in 1912 (Frank 1999: 112). Alex S. McIntyre was a "radical from the hotbed of the Phalen local" (Frank 1999: 264). 
The three editors, W.U. Cotton (1921-23), Tom Bell (1923-1924) and J.B. McLachlan (1924-1926), were all Communist Party of Canada members, and as John Manley points out, "[r]eaders were exposed not only to coverage of local and national events, but also to reports on party life abroad, numerous vignettes of socialist construction in the USSR (some of them from the pen of Roscoe Fillmore, the celebrated Nova Scotia Marxist who placed his horticultural expertise at the disposal of the USSR in 1923) and items of political analysis by leading Comintern figures" (Manley 1992: 86).

It is clear that Dawn Fraser had a major influence on this newspaper, for in the years between 1921 and 1926, thirty-four of his verses were published in The Maritime Labour Herald. David Frank points out that many of his compositions were designed for recitation: "[h]e appeared frequently at homes and parties, on street corners and in bar-rooms, at labour gatherings at the movie houses, and on one memorable occasion he read his longest epic to a summer crowd of several thousand people on the Lingan and Dominion beach" (1985: 214). Some of the longer poems were serialized and some also reappeared months or weeks after the initial publication date. In addition to his work in newspaper and pamphlet form, Fraser published four volumes of rhyme that are known by few today (Fraser 1924, 1926, 1944; n.d.). Fraser, it seems, would first publish his work in the newspaper and then gather the composed verses together for a publication. Sometimes a poem would be accompanied by an advertisement for his upcoming book. For example, following the publication of "The Widow in the Ward," Fraser writes, "[f]rom Fraser's new book, Songs of Siberia and Rhymes of the Road, second edition. The only book published of the late War that the public demanded a second edition of" (Maritime Labour Herald 30 June 1923: 4).

Much of Fraser's work depicts the mining corporation's cold, callous and uncompromising treatment of workers. For example, "The Case of Jim O'Coughlan," is a thinly veiled description of the sentencing and jailing of James Bryson McLachlan, one of the most vocal Cape Breton labour leaders of the 1920s. In 1923, McLachlan was arrested for "publishing false information likely to prejudice the public interest," but the charge was later changed to "publishing misleading information and imparting communist literature into Glace Bay" (MacEwan 1976: 111). When neither could be substantiated, a third charge of "seditious libel" was brought forth by the Crown; on this McLachlan was found 
guilty and sentenced to two years in Dorchester penitentiary. He served three months (MacEwan 1976: 111).

In "The Case of Jim O'Coughlan" Fraser provides a short history of the days leading up to McLachlan's jailing. Moreover, he satirizes and criticizes the management and supervisory personnel of the large conglomerate BESCO. He is particularly scathing in his criticism of one BESCO leader, Roy Wolvin:

Now if all the bosses that e'er was cursed,

ROY THE WOLFE 6 was called the worst,

He was the leading parasite

That fed on the workers day and night;

Greedy, growling wolf for more,

He stole the bread from the workers door,

Grew fat on starving children's cries

And filled the papers with foolish lies -

That his company couldn't afford to pay -

Yet he got three hundred dollars a day.

For doing nothing but looking wise,

Starving kids and telling lies;

Thus he promoted the capitalist game

'Til babies were taught to curse his name,

And Roy the Wolf and his thieving band

Spread distress throughout the land,

'Til Jim O'Coughlan and other men

Started one of the many fights

For Labour's cause and workers' rights.

And they called on ROY THE WOLFE to give

More of the gold that they might live,

More of the gold they had to pay

To meet the prices from day to day

(Maritime Labour Herald 1 March 1924: 2).

The use of nicknaming was a common tradition amongst miners; Fraser captures the sly and untrustworthy nature of manager Roy Wolvin by calling him "the Wolf," a name by which he was known in the mining communities (Davey and MacKinnon 2001). The poem was serialized each Saturday throughout the months of February and March, 1924. On February 16, 1924, Fraser says, "[w]orkers, cut this out and save it carefully along with your 'Pluck-Me' slips [pay stubs]. Next week we will tell you of a great Capitalist called 'Roy the Wolf' who lived many years ago" (Maritime Labour Herald 16 February 1924: 2). This direction gives an indication of how this verse was passed on. People cut texts

6. Fraser sometimes uses "Wolfe" and at others "Wolf" throughout the poem. 
out of the newspaper, saved them at home, pasted them on washhouse walls at the pit and, most importantly, discussed the content with friends and family. While initially using the mass-mediated form of the newspaper, the content of the poems was passed on via oral or face-toface means.

Many of the ills and difficulties of this period of labour/management strife and class struggle are described in this and other verses by Fraser. In addition to "The Case of Jim O'Coughlan," two other poems are devoted to this union leader: "Away False Teachings of My Youth," and "Honest Bell What Did Bruce Say" (Maritime Labour Herald 27 October 1923: 4; 2 June 1923: 4).

One other Communist Party of Canada member and labour leader, "Red" Malcolm Bruce, appears as a main figure in some of Fraser's work. Originally from Ontario, Bruce spent much time during the 1920s fighting labour's struggles in the Cape Breton coal fields. "Honest Bell What Did Bruce Say?" "The Hair Breadth Escape of Red Malcolm Bruce" and "Tell My Friend the Prison Warden I Hadn't Time to Call" all focus on events during Bruce's stay in the Cape Breton area, including a charge of libel while fighting labour's cause. Fraser points out that "Tell My Friend the Prison Warden I Hadn't Time to Call" was sung by Bruce himself (Maritime Labour Herald 2 June 1923: 4; 9 June 1923: 4; 23 June 1923: 4).

While Fraser was a gifted social commentator and poet, it is extremely difficult to assess whether or not his work entered oral tradition. If so, one would expect to find versions being sung by traditional or professional singers of the time or recorded in song collections or LP recordings. Yet, a close examination of two collections of the 1920s and 30s which were meant to provide the general public with easy access to the lyrics of some of the most popular songs on the island reveals none of Fraser's work (McCawley 1929; MacDonald 1935). Only one, "Hard Winter at the Mines," was noted by a song collector (Ronald MacEachern). ${ }^{7}$ David Frank sees Fraser's work as a

7. MacEachern collected the song from a New Aberdeen singer in 1977. It is now in the collection of the Beaton Institute, Cape Breton University. MacEachern obtained a Canada Council grant from the Canadian federal government in 1977 to collect songs in Cape Breton Island. His taped collections are deposited at the Canadian Museum of Civilization, The Miners Museum in Glace Bay, The Beaton Institute, Cape Breton University , and the Memorial University of Newfoundland Folklore and Language Archives. For a description of this collection see MacEachern (1978: 7-10). 
recitation tradition not unlike the poems of Robert Service rather than a song tradition (1986: 37). According to Frank, "[w]ith Dawn Fraser $\ldots$ we enter into the area where the oral emphasis and the spontaneity of the folk tradition seem to give way to a more conscious effort to construct a local working-class culture" (1986: 37). Yet the traditions of verse-making or folk poetry and song-making are similar, in that identical attitudes and feelings are expressed in both forms. While a song moves to the level of performance, a verse remains on the page unless it is performed as a recitation. Yet both song and verse express the widespread feelings and attitudes of working people and their families.

One possible reason why so few of Fraser's lyrics seem to have entered oral tradition lies in the fact that many are concerned with particularly harsh times and events in the history of the Cape Breton labour movement. There may be a conscious forgetting of these particular kinds of songs and verse. Fraser's verse may be too strong a reminder of a painful period for the songs to enter the lasting oral tradition. The songs composed during labour struggles, strikes, or particularly difficult times may lose their meaning for the people when the events surrounding their composition are long forgotten.

Much of Fraser's work is a part of the broadside tradition. As the editors of a reprinted volume of his poetry attest, "[h] is writings appeared in pamphlets, books, magazines, and newspapers.... Sometimes his outpourings were simply posted on a bulletin board at the main intersection at Glace Bay.... He read his verse on the streets, at union meetings, at parties, and at massive labour and political meetings at the Savoy and Russell Theatres in Glace Bay" (Frank and MacGillivray 1976: 10). Much of the industrial protest verse and song appearing in the newspaper criticizes the mining and steel corporations and their representatives while chastising "blacklegs" or scab workers and praising some of the well-known union leaders at home and abroad. For example, a verse criticizing BESCO for its exploitation of labour appears in the 26 April 1924 edition of The Maritime Labour Herald, entitled "Cape Breton Miner and BESCO:"

You will go into the mines and toil all day,

And work like a slave to keep hunger away,

You're slaving all day to provide us with coal:

But you don't get enough to keep body and soul. 
BESCO can drive in a big motor car,

For he gets the profits, whatever they are:

But you must exist there in shacks I am told,

For BESCO, that chap, has to pile up the gold.

You see what he did down in old Newfoundland:

He placed thousands of dollars in Sir Richard's hand,

In order he might that rich country control:

For BESCO, that chap, hasn't got any soul.

A nice little trip to Cape Breton he planned:

He invited the members all down to a man:

But dark clouds started rising, the weather turned cold,

So they postponed that picnic and saved BESCO's gold

(Maritime Labour Herald 26 April 1924: 5).

Using the quatrain format common in folksong and folk poetry, this verse hints at political connections between BESCO and Newfoundland Prime Minister Richard Squires (1919-1923, 1928-1932) while characterizing BESCO as an exploitative company.

Other verses in this newspaper follow the "Come-All-Ye" format, common with the broadside tradition in both the British Isles and North America. In December 1924, "Dirty Danny" appears. Written from the point of view of the captured worker, it describes how the company policeman, "Dirty Danny," catches him stealing wood from company property and the consequences of this offence:

Come All You honest workers and listen to me, When you hear my story with me you'll agree, Arrested for nothing, and glad to admit,

One evening last week when coming from the pit.

Now a Company policeman, a man I know well, And for to expose him the truth I must tell, Wherever you see him you hear people say:

'There goes Dirty Danny — belongs to East Bay."

One evening of late, coming home from the mine, As I walked along, some wood I did find, It being my intention — the truth I must say

To use it to kindle a fire the next day.

I had not gone far when I heard someone shout:

'You're taking great chances, you better look out. 
I will have you arrested and a fine make you pay."

Remarked Dirty Danny — belongs to East Bay.

Without hesitation I threw the wood down, And quickly departing for home I was bound;

But two evenings later I'll have you to know,

McAuley came afrer [sic] me and I had to go.

Now when I did appear, His Honor did say:

'Now you're charged with stealing, what have you to say?'

I pleaded not guilty, but this was no good

Dirty Danny, he swore I was caught with the wood.

I tried to explain, but I saw it was no use

His honor remarked, 'Sir I want no excuse,

You will pay $\$ 7.50$ or else put up bail,

Or the rest of this night you will spend in the jail."

Now, times being hard and my dollars but few,

I had to consider just what I could do:

To pay $\$ 7.50$ was sure hard on me

I will never forgive him, His Honor, A.B.

Now Dirty Danny, your friends are but few,

And what I hear men say if you only knew,

You'd be so ashamed you'd decide on a cruise

And go back to East Bay and hide in the spruce.

Now one thing I'll mention, I almost forgot,

I hope, Dirty Danny, hard luck is your lot,

And everyone slight you wherever you be

Just to remind you of what you did to me.

Now to conclude, and to finish my song;

The truth I have stated, you'll find it's not wrong

I hope to get even - if I live some day

With my "friend" Dirty Danny belongs to East Bay.

This verse uses many of the standard characteristics of the broadside tradition: opening formula, quatrain form, repetition of particular phrases ("Dirty Danny — belongs to East Bay"), dialogue, personal testimonial, and a closing formula. Structurally, the song is very similar to many that have entered oral tradition throughout the British Isles and North America. Nevertheless, we are told nothing about the tune of the song, nor if it has ever had a life apart from this printing. 
A famous saying in Cape Breton, "They Can't Stand the Gaff," is attributed to J.E. McClurg, Vice-President of BESCO in 1925, who suggested that miners could not take the pressure that BESCO was putting on them and that their strike would fold. ${ }^{8}$ It appears as the title to a verse in the newspaper attributed to "E.E.R." in 1925:

Seated round the table in the Council room of Hell

Sat the secret service agents of the Pit.

'Twas the regular weekly meeting when they gathered there to tell

Of the things of Earth that with them made a "hit."

They told of wars and strife and hate in every land and clime,

Of pestilence and murder and despair,

They told of orgies gluttonous in palaces sublime,

And of slums where children lived on scanty fare.

They reported on the grafter and the gambler and the sneak, Of birds of prey who feast on human kind.

They told of slimy hypocrites with countenance so meek,

And of moral perverts tainting children's minds

But the Prince of Darkness answered that their tales were small

and boring,

There was nothing new in wickedness to hear;

And he showed his grave displeasure by their indolence deploring,

Till each imp began to shrink with timid fear.

Then spoke a lively demon from a land of ice and snow,

And said, "I think I have a good report,

For in Canada I've BESCO, Sir, to help me as you know,

And to them oft in sin I must resort.

Their work has been most excellent in many years gone by,

They've bee (sic) loyal to Your Majesty, I know;

They've made little children suffer and afflicted mother's (sic) cry,

And o'er the land have scattered pain and woe.

They've starved and crushed and broken the lives of many men,

They're as merciless as Hell could have them be;

And though their slaves are starving they cut their wage again,

And laughed aloud their agony to see."

8. McClurg explained to a newspaper reporter during the 1925 strike that conditions were "getting better every day they stayed out... Poker game nothing. We have all the cards.... Let them stay out two months or six months, it matters not; eventually they will have to come to us.... They can't stand the gaff." Frank calls this "one of the most memorable statements in Cape Breton labour history," and "the remark was regarded as an offensive slur." In turn, "Standing the Gaff" became "a rallying cry of the strike" (Frank 1999: 374). 
Then spoke their chief official (who would grace our service here)

As he mocked the suffering children with a laugh;

"From these angry, cursing miners we have nothing now to fear,

For I'm positive they cannot stand the gaff."

Then Satan's brow grew gribhter (sic) and loud he laughed and long;

"That's a joke," he said, "at which all hell can laugh!

And my blessing rests eternal on the man so brave and strong,

Who mocks at pain and anguish with, 'They cannot stand the gaff"'

(The Maritime Labour Herald 14 April 1925: 4).

The composer of "They Can't Stand the Gaff” is listed as "E.E.R." to protect his or her identity. It was common for composers to include only their initials. The composer criticizes BESCO's leaders and places them in hell with support from the devil himself for making callous statements against working people. Prompted by the phrase "they can't stand the gaff," the poem castigates the company for its treatment of its workers. The poem is a visceral reaction to the company statement and represents attitudes held by many in the mining towns in the midst of the long, bitter strike of 1925. It is difficult, however, to know if this verse was ever sung or indeed if it entered oral tradition. It was most likely talked about and discussed on the streets of New Waterford and Glace Bay after it appeared on 14 April 1925. We do know that the phrase, "standing the gaff," meaning to "stay the course on a picket line" or to "stand up against injustice," has indeed entered oral tradition and still survives in Cape Breton Island. It can sometimes be heard during a strike; media reports of a recent long, bitter strike at the multinational Stora Enso pulp and paper mill in Port Hawkesbury used this phrase in headlines and in stories about the strikers (Standing the Gaff at Stora: 14).

Many verses of this nature appeared between 1921 and 1926 in The Maritime Labour Herald, some with known composers, some with anonymous authors, and some with pseudonyms. "The Empty, Raggedy Stocking," published on Christmas Eve, 1921 with an anonymous composer, paints an image of children who will not receive gifts:

What of the empty, raggedy stockings

That will hang by the chimney on Christmas Eve

With their mute appeals from the poor little owners

To the dear old Santa in whom they believe?

For their share of his presents they ask such a little, "Just a dolly to hold in my arms while I sleep, 
A little tin auto that runs when you wind it

A sounding red drum or a wooly white sheep."

The only light in their dim dark existence

Is that wonderful day when old Santa will come

With his treasure filled pack that he brings on his back

From his fairyland, snowyland, toyland home.

What beautiful dream will come to them sleeping

Under the coverlet shabby and worn.

But what of the empty, raggedy stockings

That will hang by the chimney on Christmas morn

(The Maritime Labour Herald 24 December 1921: 1).

Another significant composer of the time is J.S. (Joe) Wallace, Secretary of the Nova Scotia branch of the Canadian Labour Party in 1925. At least five songs attributed to him appeared in the Maritime Labour Herald between 1921 and 1926. One is "Voice of the Workers," composed in 1923:

Corn beef and sauerkraut

Or pig's feet and tripe

Plaster pie and cold tea

A drag on my pipe

That's my fare, for my tastes ain't fine

And I got to count the gulps from my grub when I dine.

Dollar lid, Woolworth tie

And blue cotton shirt

Grey sock and shoddy shirt

Brown beneath the dirt-

That's my style for my tastes ain't fine

And I got to stretch my dough double when I'm buyin'.

Lean to or tenement

Paper shingled shack

Drafty doors, choked flues

Outhouses at the back.

That's my home for my tastes ain't fine

The box I get when livin' like the box I get when dyin'!

What's my work you ask?

I dig coal a spell

Sheer sheep and

skin steers 
Lumberjack as well-

That's my job I hump it all the time

Making heaven from half the world, getting half for mine

(Maritime Labour Herald 6 October, 1923: 4).

Wallace's poem discusses food, clothing, housing and the diversity of work that a miner had to become accustomed to in order to survive. His other poems are "Awake," "Prayer of the Employer," "Better That," "The Five Pointed Star," "No More Deaf, No More Dumb, No More Blind," "The Rise of the Red River" and "The Red Brotherhood" (see Appendix 1). His songs clearly indicate his political stripe: along with being a poet, he was an active member of the Communist party. Joe $\mathrm{S}$. Wallace (1880-1975) was also a member of the group of Atlantic Canadian poets known as "The Song Fishermen" that included Stuart McCawley, James D. Gillis, Andrew Merkel, Charles Bruce, Kenneth and Robert Leslie, Molly Beresford, Ethel Butler and others. Alexander Kizuk says that Wallace achieved "a degree of notoriety as a Communist poet published in the Soviet Union and Canada" (1993:178). Gwendolyn Davies points out that the Song Fishermen "were to represent a Nova Scotia voice in poetry at the very time when rural values and the oral tradition were being eroded by out-migration, a changing economy and the impact of modern media" (Davies 1987: 138).

The Maritime Labour Herald gives the names of the following Nova Scotian composers: George Strattmen originally from Westville; Dannie Boutilier, Springhill; A.I. McNiven, Sydney; and Gordon Robertson, Glace Bay. Pseudonyms include: "Wage Slave," "William Waterford," "The Mixer," and "Big Guy" from Glace Bay. Other composers are listed as "student" or with abbreviations such as "F.T.R.," "P.E.P.," "R.E.F.," "E.E.R." and "G.C.S." No doubt, residents of the Cape Breton mining communities from 1921 to 1926 knew the identities of the composers in their midst despite the use of pseudonyms; all were supporters of the Maritime Labour Herald and many were members of the Communist party of Canada.

It is difficult to trace the origins of some of the composers of songs in the Maritime Labour Herald from outside the region. The writer of "The Industrial Heretics" and the "Heretics," Ralph Chaplin, was an I.W.W. (Industrial Workers of the World, whose slogan was "One Big Union") organizer. According to R. Serge Denisoff, he "wrote militant 
lyrics to the 'Battle Hymn of the Republic' and produced 'Solidarity Forever,' the official anthem of the American labour movement" (1969: 427). The famous English socialist and writer William Morris's poetry commonly appeared in newspapers, particularly the labour presses, in the 1880s and 90s (Foner 1975: 321-322). Thomas Hood's poem, "The Song of the Shirt" was published in 1923 in The Maritime Labour Herald. Foner says that this poem was the "most popular British verse in the pre-Civil war labour press in the United States" (1975: 76). It originally appeared in Punch in 1843 and "was an instant success. It was first reprinted in the United States in the Fall River Mechanic of December 7,1844 , and was widely published in an 1851 newspaper story concerned with efforts of women seamstresses in New York to form the Shirt Sewers Cooperative Union” (Foner 1975: 76). E.C. Tyler's "The Scab's Hereafter," is one of numerous anti-scab songs to be found in the labour presses of the nineteenth century. One common theme is evident in Tyler's: the scab arrives at the gates of heaven, enters, and then is exiled to hell. Foner points out that this theme is found in some of Joe Hill's songs of the late nineteenth century (1975: 247-248).

One local composer identified only by "G.C.S." composed "That Grand and Glorious Day," which was meant to be sung during a May Day parade:

In our humble home we sit, Are we broken-hearted? NIT.

We are happy and cheerful as can be,

For we know that every Red

Will be up and out of bed,

On that Grand and Glorious Day

The First of May.

Tramp, tramp, tramp, the boys are marching,

Cheer up, comrades, and be gay,

For you know we're out to fight,

To fight, with all our might.

On that Grand and Glorious Day

The First of May.

From dawn till dark at night,

We will carry on the fight,

The fight for our freedom and our cause,

Though it may be hard and long,

We will sing the same old song, 
On the Grand and Glorious Day

The First of May

Tramp, tramp, tramp, the boys are marching,

Cheer up, comrades, and be gay,

We are in this fight to win,

We will never sink but swim

On that Grand and Glorious Day

The First of May

Now that we have BESCO scared,

And the miners are prepared,

We will raise the Scarlet Banner to the sky

And we'll sing the same old hymn,

To our dear beloved Jim,

On that Grand and Glorious Day,

The First of May.

Tramp, tramp, tramp the boys are marching,

Marching on to victory

We have BESCO up a tree

And forever there they'll be

On that Grand and Glorious Day

The First of May.

We had BESCO on the bank

But our district officers sank,

When one might (sic) push would our

Greatest victory win.

But their hearts were far too small.

When they heard BESCO call,

For God's sake come to work,

Or we will fail.

Tramp, tramp, tramp, the boys are marching

Cheer up, children, and be gay,

For soon will come the day,

When your dad will draw a pay,

On the Grand and Glorious Day

The First of May

(Maritime Labour Herald 24 April 1926: 1).

This song of local composition, as with many others, makes reference to "dear beloved Jim" (MLH editor J.B. McLachlan) and to the numerous battles with BESCO. While May Day is not celebrated today in Cape Breton Island, in the 1920s marches and parades would have been 
organized on that date of international labour celebration. As Craig Heron and Steve Penfold say, "In Glace Bay, Montreal, Timmins and a few western Canadian cities, May Day parades became significant local events in the 1920s that could draw as many as 3-4000 marchers" (2005: 172). John Manley cites a May Day celebration in Glace Bay in 1923 "where some 5000 miners and their families marched behind the biggest red flag in Canada emblazoned with the legend, Long Live Communism" (1992: 75).

Some of the verses and songs that clearly did enter oral tradition were first printed in 1929 in A Book of Come All Ye's From Cape Breton and Newfoundland by Glace Bay native Stuart McCawley. This songster contains lyrics with no music. Two industrial songs, "The Yahie Miners" and "The Honest Working Man" appear in this collection amidst a potpourri of war songs, cowboy songs, Gaelic songs, broadside ballads and popular songs (McCawley 1929: 25-26). This collection provides a sense of the diversity of songs prevalent in the island at this period of industrial strife. Indeed, we are only now starting to understand the diversity of music and song of this period of Cape Breton's history. ${ }^{9}$

Stuart McCawley describes "The Honest Working Man" as "the national anthem of the Cape Breton worker many years ago and a popular song with the troops in World War I. It was written as a piece of irony aimed at the importation of surplus labour in the summer months. Anyone not porridge-bred and Gaelic was a foreigner" (1929: 7). Although it is difficult to assess its popularity, the song seems to have been widespread in Cape Breton mining communities. Helen Creighton and Margaret Sargent collected versions of this song and as recently as 1978, Ron MacEachern recorded a version sung by Charlie MacKinnon, a well-known performer who has cut a number of recordings of Cape Breton music (MacEachern 1978). After I delivered a presentation in 1982 to the Old Sydney Historical Society in the Lyceum Building, Charlotte Street, Sydney, an older man greeted me and proceeded to sing a version of "The Honest Working Man." He claimed

9. A colleague recently asked me if the Centre for Cape Breton Studies at Cape Breton University was interested in early 78 recordings of Lebanese songs brought to the island with Lebanese settlers who came to work in the steel mill in early twentieth century Sydney. The collection was slated for disposal. As more of this kind of material is gathered, we will obtain a better understanding of the diversity of song brought to the Island by numerous ethnic and cultural groups. 
he had not heard the song in many years. Although evidence of its origins is sparse, it has had a long life in the Cape Breton industrial communities. As David Frank says, "it is difficult to date this song, but it again appears to be associated with the late nineteenth century period of development in the industry, when coal mining was almost entirely seasonal and the chief competition for local labour came from Acadians and Newfoundlanders rather than European immigrants" (1986: 29). The song is concerned with the importing of Newfoundlanders and "foreign labourers" into Cape Breton, a common practice in many North American industrial frontiers:

\section{Chorus}

'Way down in East Cape Breton, where they knit the sock and mitten, Chezzetcookers represented by the dusky black and tan; May they never be selected, and home rule be protected, And never be connected with the honest working man.

But raises high my dander, next door lives a Newfoundlander, Whose wife you cannot stand her, since high living she began, Along with the railroad rackers, ${ }^{10}$ also the codfish packers, Who steal the cheese and crackers from the honest working man.

When leaves fall in the autumn and fish freeze to the bottom, They take a 3 ton schooner and go round the Western shore; They load her with provisions, hard tack and codfish mizzens, The like I never heard of since the downfall of Bras d'Or.

The man who mixes mortar, gets a dollar and a quarter, The sugar factory worker he gets a dollar ten, While there's my next door neighbor, who subsists on outside labour, In the winter scarcely earns enough to feed a sickly hen.

They cross the Bay of Fundy, they reach her on a Monday, Did you see my brother Angus? Now tell me if you can; He was once a soapbox greaseman, but now he is a policeman, Because he could not earn a living as an honest working man (McCawley 1929: 7).

10. According to the US Department of Labor Occupational Classification System Manual, a racker is a laborer whose occupations "are not specifically identified, who perform unskilled, simple duties, primarily manual, that may be learned within a short period of time and that require little or no independent judgment" (US Dept. of Labor Occupational Classification System Manual). 
Although in McCawley's printed version no tune is included, Edith Fowke states it is Irish, from the Tipperary song, "The Hills of Mallabon," composed in 1840 (1969: 40). Charlie MacKinnon changed the words of the first verse, so he would not offend his Newfoundland friends (O’Donnell 1992a: 114):

I think I'll go meander with my friend the Newfoundlander;

He is the finest fellow to ever grace the land

His name is John Allie; he's from the Codroy Valley.

He works in the coal mines with the honest working man

(O’Donnell 1992a: 113).

This change reflects a reversal of the original verse's intention of criticizing Newfoundlanders. MacKinnon indicates that a good relationship existed with the Codroy Valley Newfoundlanders who came to the coal mining towns in the winter months to supplement their farm incomes. Many had roots in the Cape Breton Island Gaeltacht and Acadian fishing communities (MacKinnon 2002). Essentially, the song is about scab labour and, as Jack O'Donnell notes, these types of songs "are common in mining communities throughout the world" (1992a: 114). As David Frank illustrates, the variations in versions show that its original connotations had begun to change by the early years of the twentieth century. "By the 1920s the song appeared to have lost much of its original meaning. 'It is sung at picnics and parties,' wrote Stuart McCawley in a newspaper column in 1926, 'and goes best after a few shots of strong rum. The swing of the song is good and the local touches are laugh provoking”' (1986: 30). Another verse was added by 1935, again changing the original meaning of the song:

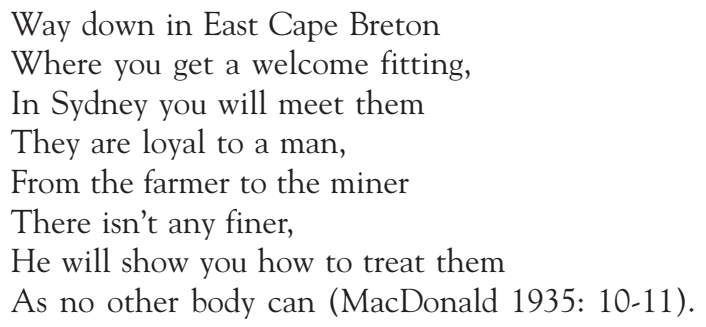

As Frank suggests, the ethnic rivalries, once common in the industrial setting, were "being superceded by a local sense of identity as Cape Bretoners" (1986: 30).

"The Yahie Miners" is also concerned with the attitudes held by established coal miners toward migrants who threaten their jobs. David 
Frank argues that the term "Yahie," derived from "Dhachaich," the Gaelic word for home, may describe the Gaelic workers who flocked to the industrial communities from Cape Breton's rural districts (1986: 28). The song, however, mentions Yahies from "Rocky Boston," suggesting that these workers may have been coming from beyond the shores of Cape Breton. The composer may be making a reference to the many Newfoundlanders travelling to and from what was referred to as "the Boston States." Many stayed to find permanent employment in the steel mill and coal mines. This song not only seems to have been widespread in the Cape Breton industrial area, but is internationally known, with variants throughout the British Isles and North America. The Cape Breton variants seem to be derived from the British song, "The Blackleg Miners" which can be dated to a lockout in the north England community of Durham in 1844 (Frank 1986: 27). McCawley states, "This Come-All-Ye is sixty years old and still sung in District 26" (1929: 21). ${ }^{11}$ The version appearing in McCawley's book does not offer the name of a performer, nor does it include the music of the tune:

Early in the month of May

When all the ice is gone away.

The Yahies, they come down to work

With their white bags and dirty shirts,

The dirty Yahie miners.

Chorus

Bonnie boys, Oh won't you gang,

Bonnie boys, Oh won't you gang,

Bonnie boys, Oh won't you gang,

To beat the Yahie miners.

They take their picks and they go down

A-digging coal on underground,

For board and lodging can't be found

For dirty Yahie miners.

Into Mitchell's they do deal,

Nothing there but Injun meal.

Sour molasses will make them squeal,

11. District 26 is the number given to the Cape Breton Island coal miners' local of the United Mine Workers of America. 
The dirty Yahie miners.

Join the Union right away,

Don't you wait until after pay,

Join the Union right away,

You dirty Yahie miners.

Mrs. McNabb, she keeps the Hall

Where the Yahies they do call,

You'll see them flock around the Hall,

The dirty Yahie miners.

Don't go near MacDonald's door,

Else the bully will have you sure;

For he goes 'round from door to door

Converting Yahie miners.

Jimmie Brinick he jumped in,

Caught MacKeigan by the chin,

Give me Maggie though she's thin,

For I'm no Yahie miner.

From Rocky Boston they do come,

The damndest Yahies ever found,

Around the office they do crowd,

The dirty Yahie miners.

The Lorway road is now clear,

There are no Yahies on the beer,

The reason why there are none here,

They're frightened of the miners (1929: 20-21).

The version published by Jack O'Donnell was collected by Alphonse MacDonald to the tune of "Blackleg Miners" (O'Donnell 1992a: 115116). The topics mentioned in the song include: the difficulty faced by workers trying to find lodging in a booming industrial town; dealings with a merchant who, it seems, is only able to provide the newcomers with subsistence food; the pressures to join the union; and fighting and drinking. In a sense, the song offers an ethnographic description of the kinds of difficulties faced in any booming industrial town in North America. ${ }^{12}$

12. David Frank mentions that a Cape Breton Island song contest in 1966 elicited a song, "Kelly's Cove" that appears to be a version of "The Yahie Miners" (Frank 1986: 29). 
It is interesting to note that one of the most prolific song collectors of the twentieth century in the Maritimes, Helen Creighton, failed to record examples of these kinds of songs on her two recording expeditions to Cape Breton Island. ${ }^{13}$ Nevertheless, judging by a comment in her biography, she was aware that such a song and verse tradition existed:

There were miners at Inverness, and I felt they too would have songs. When we saw one walking home with his lunch box we offered him a ride. I said, "Have you miner's songs down here?" and was delighted when he said, "Yes, we have a lot of them." I said, "What are they like?" He looked so surprised that I said, "How do they go?" To this he answered, "Mine are here." That seemed a strange remark so I said, "Who sings them?" Then he began to laugh. "Did you say songs? I thought you said sons" (Creighton 1975: 145).

Despite the confusion, it is clear that Creighton assumes that male coal miners should know some mining songs.

Of the 124 songs in the collection analyzed here, at least six were composed by women. Ella Wheeler Wilcox published "Here and Now" and her work appeared in the American presses and was associated with the early American Federation of Labour (Foner 1975: 168-169, 186). Other women composers include Celia Baldwin, Rebecca Buhay, Elma Ehelich Levinger, and unnamed female Glace Bay students. There may well be other women composers amongst those who chose to use abbreviations or pseudonyms to disguise their identities. The actions and roles of non-waged working class women have been largely ignored in some of the early Cape Breton labour history scholarship. Steven Penfold's seminal work in this area indicates that "the dominant historical view of women in Canadian coal-mining communities has placed them at home and dependant on men, if they are mentioned at all" (1994: 21). Nevertheless, women played active roles during strikes, organized crowd actions and were often the financial controllers and budgeters of

13. It might have been particularly difficult for a single female collector in the 1920s and 30s to establish sufficient rapport with miners and their families, though numerous examples existed on the island at the time of her extensive collecting expeditions. This absence of mining songs in Creighton's collection serves as a reminder for folksong analyzers to exercise caution when making cultural generalizations from early song collections. The biases and limitations of collectors and collections are seldom discussed in interpretations of early song collections. 
households who made a little money stretch as far as possible (Frank 1983: 137-143).

We know about Rebecca (Becky) Buhay because of Joan Sangster's work on the history of women on the left in Canada in the twentieth century (1989). Buhay, a pivotal leader in the Communist Party of Canada in the 1920s and 30s, was from a working class Jewish family which emigrated to Montreal from London's east end. She worked as a photo finisher, tobacco worker and garment industry worker (Sangster: 1989: 65). She helped organize the Amalgamated Clothing Workers Union of America, went to New York City toward the end of World War I and became involved in American socialist politics. Sangster says, "Buhay's high profile led to government surveillance and her hasty return to Montreal in late 1919" (66). On her return to Canada she helped organize the Montreal Labour College and by 1922 was "deeply involved in the [Communist] Party [of Canada]" (66). She moved to Toronto to Communist Party headquarters by 1929 and became secretary of the Canadian Labour Defense League and head of the Women's department (66). Sangster describes an incident that provides insight into Buhay's personality and commitment to her cause: "Buhay... had... salient experiences with the police. In the middle of a public meeting during the free speech fights, the police raided the theatre, whisked the speakers off the stage, and dropped the curtain. Buhay, not one to be easily silenced, crawled under the curtain and began to denounce the police to an enthusiastic audience. Suddenly, she began to faint and was grabbed by Tim Buck; she had finally been silenced by police tear gas" (66).

Three of Buhay's songs appeared in the Maritime Labour Herald in 1924: "The Machine Awakes," "Daughters Awake" and "The Song of the Street." "Daughters Awake" provides a clear example of her position on equality for women in society; she asks women be forceful in advocating change:

Too long you've been the thralls of men, In kitchen, factory and den,

Too long you've paid the price for all Without a voice - unheard; your call;

You've borne the children of each age,

Yet never a word in history's page.

Demand the right to have your say 
In the making and building of the day!

(Maritime Labour Herald 16 August 1924: 3).

Her songs ask workers to rise up and change the capitalistic society in which they are ensnared. In "The Machine Awakens" she says:

The roar of the machines breaks into song:

"Revolt!" It cries "Revolt", "revolt!"

Awaken to action these automatons of flesh and blood,

Gather together the bundle herders,

Stop the rhythm of their feet and hands,

"End this hell!" "End this hell!"

And the dreamer into action is stirred

(Maritime Labour Herald 19 July 1924:3).

It is clear from these short excerpts that women's voices were indeed heard in protest songs within the Maritime Labour Herald even though it appears that the majority of composers were men. Steven Penfold has clearly outlined the way in which symbols of gender were employed in this period and how women's domestic labour “constituted an important, but hidden, support mechanism for the union movement in Cape Breton" (Penfold 1994: 43). It is in songs such as those composed by Buhay that we get a glimpse of the 1920s quest for equal rights for women, and of the role that women played in the class struggles of the 1920s.

This essay, exploring a small corpus of protest songs composed during the 1920s that appeared in The Maritime Labour Herald, shows that newspapers are valuable sources for understanding the diversity of music and verse in Canadian industrial communities in the early years of the twentieth century. These compositions played a significant role in helping to develop a working class ideology within the community throughout the 1920s. Dawn Fraser's radical prose was a prominent feature of the newspaper, a host of other self-identified composers were frequent contributors, and a select group of song and verse writers used pseudonyms and abbreviations to partially conceal their identities. Some of the songs included here have a life in tradition, while others do not. Whether or not they were sung, however, the fact of their publication helps define the state of social discontent in this period of Cape Breton's history. One scholar points out that songs or verses like this are "less likely to be taken seriously, and thus censored or repressed, than more 
rational and literal forms of communication, such as speeches or pamphlets" (Lewis 1985: 155).

I have also shown that the pressures of the working class community were clearly articulated in these compositions. As well, the songs and verses certainly helped to promote solidarity amongst miners and their families in their struggle against mine managers and BESCO during the various strikes and work stoppages of the time. Many of them are oppositional and offer an alternative vision of the kind of society working class families would like to have. This constructive dissent is similar to what Greenhill has found in her study of Ontario folk poetry: "[t]hey present - and usually actively advocate - alternatives to the status quo, to mainstream culture, to 'progress,' or even to change" (1989: 214).

There are currently no operating coal mines in Cape Breton. Nevertheless, every June $11^{\text {th }}$, coal mining communities hold a holiday called Davis Day to commemorate the killing of coal miner William Davis by Company Police on the picket line during the $1925 \mathrm{New}$ Waterford strike. A number of songs re-narrating the events of that day have been composed. The Davis Day celebration begins with an ecumenical church service followed by a one minute silence for departed brothers and sisters, and the placing of wreaths at a miner's monument by municipal officials, individuals and unions. The day also includes speeches by union leaders, closing prayers and songs sung by the Men of the Deeps Choir. The Choir always keeps June $11^{\text {th }}$ free to perform at this event.

Long after the mines, the coal miners and their descendants are gone, the song and verse of the day will continue to provide a useful framework for understanding the complexities of daily life and the expressive culture and attitudes of working people living in industrial towns throughout the world. 


\section{References}

American Folklore Society. 1984. Folklore/Folklife. Washington, DC: American Folklore Society.

Creighton, Helen.1975. A Life in Folklore. Toronto: McGraw-Hill Press. Davey, William and Richard MacKinnon. 2001. "Nicknaming Patterns and Traditions among Cape Breton Coal Miners." Acadiensis 30 (2): 71-83.

Davies, Gwendolyn. 1987. "The Song Fishermen: A Regional Poetry Celebration." In Larry McCann ed., People and Place: Studies of Small Town Life in the Maritimes: 137-150. Fredericton: Acadiensis Press.

Denisoff, R. Serge. 1966. "Songs of Persuasion: A Sociological Analysis of Urban Propoganda Songs." Journal of American Folklore 79 (314): 581-589.

- 1969. "Folk Music and the American Left: A GenerationalIdeological Comparison." The British Journal of Sociology 20 (4): 427-442.

Foner, Philip S. 1975. American Labour Songs of the Nineteenth Century. Urbana, Chicago and London: University of Illinois Press.

Fowke, Edith. 1969. "Labour and Industrial Protest Songs in Canada." Journal of American Folklore. 82 (323): 34-50.

Frank, David. 1971. "Coal Masters and Coal Miners: Strikes and Roots of Class Conflict in the Cape Breton Coal Industry." Dalhousie University thesis.

. 1983. "The Miner's Financier: Women in the Cape Breton Coal Towns, 1917." Atlantis VIII (2):137-143.

. 1985. "Tradition and Culture in the Cape Breton Mining Community in the Early Twentieth Century." In Ken Donovan ed., Cape Breton at 200: Historical Essays in Honor of the Island's Bicentennial 1785-1985: 203-218. Sydney: University College of Cape Breton Press.

__ 1986. "The Industrial Folksong in Cape Breton." Canadian Folklore Canadien 8 (1-2): 21-42. 1999. J.B. McLachlan: A Biography. Toronto: James Lorimer. and Don MacGillivray eds. 1976. Introd. to Echoes From Labor's War, by Dawn Fraser. Toronto: New Hogtown Press.

Fraser, Dawn. 1924 [1919]. Songs of Siberia and Rhymes of the Road. Glace Bay, NS: Eastern Publishing Co.

- 1926. Echoes From Labor's War. n.p. 1944. Narrative Verse and Comments including Songs of Siberia, Echoes from Labor's War, Fraser's Filosophies [sic] All the Old Stuff and a Lot of New Ones. Glace Bay, NS: Eastern Publishing. 
. 1976. Echoes From Labor's War, by Dawn Fraser. Toronto: New Hogtown Press.

- n.d. Great War Story: The Crime of Johnny Kyle and Other Stuff. Glace Bay, NS: Eastern Publishing.

Green, Archie. 1972. Only a Miner: Studies in Recorded Coal-Mining

Songs. Urbana, Chicago and London: University of Illinois Press.

Greenhill, Pauline. 1989. True Poetry: Traditional and Popular Verse in

Ontario. Montreal and Kingston, London, Buffalo: McGill-Queen's University Press.

- 2003. "Radical? Feminist? Nationalist? The Canadian Paradox of Edith Fowke," The Folklore Historian 20: 22-33.

Greenway, John. 1970. American Folksongs of Protest. New York: Octagon Books.

Heron, Craig and Steve Penfold. 2005. The Workers' Festival: A History of Labour Day. Toronto: University of Toronto Press.

Jones, Michael Owen. 1985. "On Folklorists Studying Organizations: A Reply to Robert S. McCarl." American Folklore Society Newsletter 14 (2): 54-68.

Kizuk, Alexander. 1993. "Molly Beresford and the Song Fishermen of Halifax: Cultural Production, Canon and Desire in 1920s Canadian Poetry." In Gwendolyn Davies ed., Myth and Milieu: Atlantic Literature and Culture 1918-1939: 175-194. Fredericton: Acadiensis Press.

Korson, George. 1960. Black Rock: Mining Folklore of the Pennsylvania Dutch. Baltimore: Johns Hopkins Press.

___ 1964. Minstrels of the Mine Patch. Hatboro, Pennsylvania: Folklore Associates.

- 1965. Coal Dust on the Fiddle. Hatboro Pennsylvania: Folklore Associates Inc.

Lewis, George H. 1985. "The Role of Music in Popular Social Movements: A Theory and Case Study of the Island of Hawaii, USA." International Review of the Aesthetics and Sociology of Music. 16 (2): 153-162.

Lloyd, A.L. 1952. Come All Ye Bold Miners. London: Lawrence and Wishart.

MacEachern, Ron. 1978. "Collecting on Cape Breton Island." Canadian Folk Music Society Bulletin, 13 (3): 7-10.

MacEwan, Paul. 1976. Miners and Steelworkers. Toronto: Hakkert and Company.

MacDonald, Alphonse. 1935. Cape Breton Songster. Sydney: Privately Published.

MacGillivray, Don. 1973. "Cape Breton in the 1920s: A Community Besieged." 
In Brian Tennyson ed., Essays in Cape Breton History: 49-67. Windsor, ON: Lancelot Press.

1991. "Work Poetry/Poésie de Travail: The Industrial Verse of Slim Mcinnis." Labour/Le Travail 28: 271-284.

MacKinnon, Richard. 2002. Vernacular Architecture in the Codroy Valley.

Ottawa: National Museum of Civilization.

Manley, John. 1992. "Preaching the Red Stuff: J.B. McLachlan, Communism and the Cape Breton Miners, 1922-1935." Labour/Le Travail 30:65-114.

McCarl, Robert S. Jr. 1978. "Occupational Folklife: A Theoretical Hypothesis." Western Folklore 37 (3): 145-160.

McCawley, Stuart. 1929. Cape Breton Come All Ye: A Book of ComeAll-Ye of Cape Breton and Newfoundland. Glace Bay: Brodie Printing Service.

Narváez. Peter. 2005. "Tradition and Labour: The Strike Songs of a Newfoundland Company Town.” In Martin Lovelace, Peter Narváez and Diane Tye eds., Bean Blossom to Bannerman: Odyssey of a Folklorist: A Festschrift for Neil Rosenberg: 299-342. St. John's: Memorial University of Newfoundland Folklore and Language Publications.

O'Donnell, John C. 1975. The Men of the Deeps. Waterloo: Waterloo Music Company.

1992a. And Now the Fields are Green: A Collection of Coal Mining Songs in Canada. Sydney: University College of Cape Breton Press. 1992b. "Join the Union or You'll Die: Songs Relating to the Labour Union Movement in Canada's Coal Mining Communities." Canadian Folklore Canadien 14 (2): 113-136.

Penfold, Steven. 1994. "Have You No Manhood in You? Gender and Class in the Cape Breton Coal towns, 1920-1926." Acadiensis XXIII (2): 21-44.

Rhos Male Voice Choir: http://www.bbc.co.uk/wales/music/sites/ rhos_male_voice_choir/

Sangster. Joan. 1989. Dreams of Equality: Women on the Canadian Left, 1920-1950. Toronto: McClelland and Stewart.

Socialist Worker On-line. http://www.socialistworker.org/20042/ 500Supp/500Supp_WhereToBegin.shtml

Standing the Gaff at Stora. 2006. Shunpiking Magazine 11 (1): 14.

US Dept of Labor Occupational Classification System Manual. http:// www.bls.gov/ncs/ocs/ocsm/comH889.htm Last modified: October 16, 2001.

Williams, Gareth. 1998. Valleys of Song: Music and Society in Wales, 1840-1914. Oxford: Clarendon Press. 


\section{Appendix}

\section{Title}

I.S. Henri's Manual of the Heritage of

Canada and the United States

The Empty, Raggedy Stocking

Creed of Big Buisness

Good Times

The Soldiers Bonus

The Striker

Help the Children

The Parasites

Last Post

Canada Free

I Go Upon a Quest

Sydney's Jaundiced Chief

The Red Flag

The Parasites

Honest Bell, What Did Bruce Say

The Hair Breath

Escape of Red

Malcolm Bruce

Make Room for Life

The Song of the Shirt

The Tale of the Tom

Cat or The Jewells of Nick Czar

Awake

Tell My Friend, the Prison Warden, that I Hadn't Time to Call

The Widow in the Ward

District 26

Mr. Recruiting Officer Didn't You Take

My Name

The Scab's Hereafter

Henry Doubb on Judgment Day:

A Vision SATIRIC

The World for the Worker

Prayer of the Employer

Voice of the Workers

Away False Teachings of My Youth

Better That

Away False Teachings

My Youth

Is it Peace

\section{Composer / Author}

Date
Wage Slave

H. Gay

A.I. McNiven

John F. Waddington

Dawn Fraser

1922

I.S. Henri and

Sir Adolphe Routhier

George D. Herron March 1, 1915

J.P. McNeil

Dawn Fraser

Dawn Fraser

Dawn Fraser

Porte Wood Taylor

Thomas Hood

Dawn Fraser

J. Wallace

Dawn Fraser

Dawn Fraser

S. Major

Dawn Fraser

E.C. Turner

John S. Clarke

S. Sharp

J.S. Wallace

J.S. Wallace

Dawn Fraser

J.S. Wallace

Dawn Fraser 
Place

Music / Air / Sung By

\section{Maritime Labor Herald}

Lucy Locket Lost her

December 3, 1921, 5.

Pocket (otherwise known

as Yankee Doodle Dandy)

December 24, 1921, 1.

February 25, 1922, 5.

March 18, 1922, 6.

Sydney, NS

North Sydney, NS

\section{O Canada}

March 18, 1922, 6.

April 29, 1922, 7.

May 6, 1922, 5.

June 3, 1922, 6 .

October 7, 1922, 7.

Florence, Italy

The Maple Leaf

My Mayland

June 9, 1923, 4.

June 9, 1923, 5 .

June 14, 1923, 2.

June 23, 1923, 4.

June 23, 1923, 4.

As sung by Malcolm Bruce

June 30, 1923, 4.

July 7, 1923, 4 .

July 7, 1923, 4.

August 11, 1923, 4.

September 1, 1923

September 22, 1923

September 29, 1923, 4.

October 6, 1923

October 27, 1923, 4.

December 29, 1923, 4.

December 29, 1923, 5 .

Cape Breton, NS

January 5, 1924, 4. 


\section{Title \\ Composer/Author \\ Date}

The Shoppers

Saturday Night

The Strikebreaker

The Case of Jim

$\mathrm{O}^{\prime} \mathrm{Coughlin}$

The Case of Jim

Dawn Fraser

O'Coughlin Chapter 2--

Dawn Fraser

Roy The Wolfe

The Case of Jim

Dawn Fraser

$\mathrm{O}^{\prime}$ Coughlin (continued

from last week)

Vote it Down

The Case of Jim

$\mathrm{O}^{\prime}$ Coughlin (continued)

The Day of Days

The Commune

You Have Nothing To

Lose But Your Chains

A Fair Trial

Dalyrimple and Barrett

CB Miner and BESCO

The Rise of the Red

River

The Parasites Exposed

Wearing of the Red

Stringhm Mine

Dawn Fraser

William Morris

Simon Felshin

Henry Roenne

March 18, 1871

William Waterford

F.T.R.

J.S. Wallace

Dawn Fraser

Dawn Fraser

May 1, 1924

(written between

2:00 and 2:05)

War

The Wearing of the Red

The Reward

Mother When the

Whistles Blow

The Red Flag

The Industrial

Heretics

O Liberty the One I Mean

To Edith

Song of Separation

Blame it On the Reds

The Last Signal

SALAAM

The Red Brotherhood

The Machine Awakes

Here and Now

The Crime of Johnny

Kyle Part One

Send the Bill to BESCO

Henry George Weiss

Dawn Fraser

Dawn Fraser

George Strattmen

Celia Baldwin

Ralph Chaplin

George Strattmen

Ralph Chaplin

Ralph Chaplin

George Strattmen

Ralph Chaplin

Joe Wallace

Rebecca Buhay

Ella Wheeler Wilcox

Dawn Fraser

Dawn Fraser

Dawn Fraser

Kyle Part Two

The Crime of Johnny

Kyle Part Three

Dawn Fraser 
West Virginia

Cape Breton, NS

Cape Breton, NS

Cape Breton, NS

England

Cape Breton, NS

Cape Breton, NS

Cape Breton, NS

Cape Breton, NS

Cape Breton, NS

Cape Breton, NS

Cape Breton, NS

Westville, NS

Westville, NS

Florence, CB, NS

Cape Breton, NS

Cape Breton, NS

Cape Breton, NS

Cape Breton, NS
January 5, 1924, 4.

January 19, 1924, 4.

February 16, 1924, 2.

March 1, 1924, 2.

March 8, 1924, 2.

March 8, 1924, 3.

March 15, 1924, 4.

March 22, 1924, 4.

March 22, 1924, 4.

March 29, 1924, 8.

April 5, 1924, 4.

April 26, 1924, 4.

April 26, 1924, 5.

May 3, 1924, 4.

May 3, 1924, 6.

May 3, 1924, 8.

May 10, 1924, 4.

May 10, 1924, 4.

May 17, 1924, 2.

May 17, 1924, 3.

May 17, 1924, 8.

May 31, 1924, 1.

May 31, 1924, 7.

June 7, 1924, 1.

June 21, 19204, 1.

June 21, 1924, 5.

June 21, 1924, 7.

June 28, 1924, 1, 4.

July 5, 1924, 8 .

July 19, 1924, 3 .

July 26, 1924, 4.

July 26, 1924, 6 .

August 9, 1924, 1.

August 9, 1924, 6.

August 9, 1924, 6. 
Yes, What's da Use

The Perfect Day

The Crime of Johnny

Kyle Part Four

The Old Song Resung

Daughters Awake

The Crime of Johnny

Kyle Part Five

The Shutdown

The Song of the Street

I Was a Stranger and

they Took Me In

I Was a Stranger and

they Took Me In

Lord Loves Ya Lewis

They took Me In

(continued)

I Walked Right In and

He Turned Around and

He Walked Right Out

Again

I Was A Stranger and

Took Me In (continued)

Wayfarers

A Nurse

The Christians

Greetings! Little Labor

Herald. What? Three

Years Old Today.

Overheard at Caledonia

The Christians

(continued)

The Christians

(continued)

The Christians

(continued)

Revolution

The Christians

(continued)

To the Poets

Dirty Danny

The Vampire II

To the Public

God of the fighting Clan

Sons of a Nation

What is Slavery

The Worm and the Vulture

In Pastures Bare He

Leadeth Us
George Strattmen

Dawn Fraser

Elma Ehelich Levinger

Rebecca Buhay

Rebecca Buhay

Dawn Fraser

Dawn Fraser

Dawn Fraser

Dawn Fraser

Wordsworth

Dawn Fraser

Dawn Fraser

Dawn Fraser

Dawn Fraser

Dawn Fraser

Ferdinand Freiligrath

Dawn Fraser

"The Mixer"

"P.E.P."

Bert Leach

Donnie W. Boutilier

John Niehardt

Thomas Campbell

Shelley

"R.E.F." 
Cape Breton, NS

Florence, CB, NS

Cape Breton, NS

Cape Breton, NS

Cape Breton, NS

Cape Breton, NS

Cape Breton, NS

Cape Breton, NS

Cape Breton, NS

Cape Breton, NS

Cape Breton, NS

Cape Breton, NS

Cape Breton, NS

Cape Breton, NS

Germany

Cape Breton, NS

Cape Breton, NS

Springhill, NS

Nova Scotia

Glasgow, Scotland

New Waterford, CB, NS
August 9, 1924, 6.

August 9, 1924, 7.

August 16, 1924, 6.

August 16, 1924, 3.

August 16, 1924, 3.

August 23, 1924, 6.

August 30, 1924, 3.

August 30, 1924

Auust. 30, 1924, 6.

September 6, 1924, 6 .

September 13, 1924, 1. September 20, 1924, 6.

September 27, 1924, 1.

October 11, 1924, 6.

October 11, 1924, 8 .

October 18, 1924,.2

October 18, 1924, 6 .

October 25, 1924, 4.

October 25, 1924, 6 .

October 25, 1924, 6 .

November 1, 1924, .6

November 8, 1924, 6 .

November 15, 1924, 1.

November 15, 1924, 6.

December 6, 1924,.4

December 13, 1924, 6 .

December 20, 1924, 1, 4.

January 3, 1925, 3.

January 17, 1925, 2.

February 14, 1925, 3.

February 21, 1925, 1.

February 28, 1925,.1

March 21, 1925, 3. 


\begin{tabular}{|ll}
\hline Title & Composer/Author \\
\hline The Five Point Star & Date \\
The Workers Child & Thomallace Campbell \\
Bread and Roses & Joseph Oppenheim \\
The Battle of Glace Bay & Lloyd Roberts \\
Can You Stand the Gaff & Patrick Owney \\
They Can't Stand the Gaff & "E.E.R." \\
The Workers Cry & John C. Nechardt \\
The Gaff & Gordon Robertson \\
No More Deaf, No More & J.S. Wallace \\
Dumb, No More Blind & \\
The Dauntless Three & "Big Guy" \\
The Scab & \\
The May Day Call & \\
Saturday's Child & Countee P. Cullen \\
The Factory Child & \\
I Charge You, & Dawn Fraser \\
British Workers & \\
That Grand and Glorius Day & G.C.S. \\
Stand Up for Justice & Student \\
The Heretics & Ralph Chaplin \\
The Red Flag & James Connell \\
We'll Never Let the & Student \\
Red Flag Fall & \\
A Most Unfriendly Act & Dawn Fraser \\
Cape Breton's Curse & Dawn Fraser \\
Adieu, Adieu & \\
The Red Flag & James Connell \\
\hline
\end{tabular}




\section{Place}

Halifax,N S

Nova Scotia

New England

Ottawa, ON

Memphis, TN

Cape Breton, NS

New Aberdeen, CB, NS

Cape Breton

Glace Bay, CB, NS

Glace Bay, CB, NS

Cape Breton, NS

Cape Breton, NS

Cape Breton, NS

Glace Bay, CB, NS

Cape Breton, NS

Cape Breton, NS

\section{Music/Air/Sung by Maritime Labor Herald}

March 28, 1925, .

March 28, 1925, 1.

March 28, 1925, 1.

April 4, 1925, 3.

April 14, 1925, 4.

April 14, 1925, 4.

April 11, 1925, 1.

April 11, 1925, 2.

January 30, 1926, 3.

February 27, 1926, 3.

March 20, 1926, 3.

April 10, 1926, 1.

April 17, 1926, 1.

April 17, 1926, 3.

April 24, 1926, 1.

April 24, 1926, 2.

May 8, 1926, 3.

May 15, 1926, .4

May 22, 1926, 3.

June 26, 1926, .1

July 10, 1926, 1 .

July 10, 1926, 3. 